Original Research Article

\title{
Effects of Salacia oblonga on aluminium induced changes in membrane ATPases in brain cortex and hematological parameters in Wistar albino rats
}

\author{
Divyashanthi C. M. ${ }^{1 *}$, Nandhini A. ${ }^{2}$, Barathane Datchanamurthy ${ }^{3}$
}

\begin{abstract}
${ }^{1}$ Department of Pharmacology, Vinayaka Missions Medical College, Vinayaka Missions Research Foundation (DU), Karaikal, Puducherry, India ${ }^{2}$ Lecturer, Asan memorial dental college and hospital, Chengalpattu, Kanchipuram district, Tamil Nadu, India ${ }^{3}$ Department of Pharmacology, Mahatma Gandhi Medical College and Research Institute, Sri Balaji Vidyapeeth, Puducherry, India
\end{abstract}

Received: 21 March 2019 Accepted: 11 April 2019

*Correspondence to: Dr. Divyashanthi C.M., Email: dishanthii@gmail.com

Copyright: (C) the author(s), publisher and licensee Medip Academy. This is an openaccess article distributed under the terms of the Creative Commons Attribution NonCommercial License, which permits unrestricted noncommercial use, distribution, and reproduction in any medium, provided the original work is properly cited.

\begin{abstract}
Background: The current study was done to evaluate the effect of hydro alcoholic extract of Salacia oblonga on aluminum induced toxicity in brain cortex and blood in Wistar albino rats.

Methods: The experimental animals were divided into four groups, each group comprising of six animals for 36 days of experimental duration. We investigated $\mathrm{Na}^{+} / \mathrm{K}^{+}, \mathrm{Mg} 2^{+}, \mathrm{Ca} 2^{+}$ATPases enzyme activity in brain cortex and hematological changes if any, upon administration of aluminum chloride $\left(\mathrm{Alcl}_{3}\right)(300 \mathrm{mg} / \mathrm{kg}$ b.w), hydro alcoholic extract of Salacia oblonga (67 mg/kg b.w) and $\mathrm{Alcl}_{3}{ }^{+}$ Salacia oblanga with control (distilled water).

Results: In brain cortex, Salacia caused an increased in activity of ATPases. Combined administration of Salacia suppressed the influence of aluminum on the ATPases in the brain cortex $(\mathrm{p}<0.05)$. Both aluminum as well as Salacia did not cause any alteration in the hemoglobin content of blood in Wistar albino rats. The erythrocytes count was also not altered by treatment with either aluminum or Salacia. Combined treatment with Salacia suppressed the influence of aluminum with reference to neutrophil count and significant increases in monocyte as well as lymphocyte count were seen. Thus, repeated administration of aluminum causes a decrease in neutrophil and increase in lymphocyte count.

Conclusions: All the ATPases in brain cortex were found to be affected by aluminum administration and Salacia is found to counteract the ATPase effect to a particular extent implying the presence of an active principle that can counteract the aluminium toxicity indicating its possible usefulness in aluminum toxicity.
\end{abstract}

Keywords: Aluminium, Membrane ATPase, Salacia oblonga extract Toxicity

\section{INTRODUCTION}

Cell membrane integral proteins acting as enzymes such as ATPase mediates the toxic effect of many metals. Living system needs a continuous input of energy for maintaining homeostasis. The energy rich compounds are stored as ATP and its derivatives in a biosystem. ATPases are enzymes that catalyze the decomposition of adenosine triphosphate (ATP) into adenosine diphosphate (ADP) and a free phosphate ion. ${ }^{1}$ This dephosphorylation reaction releases energy, which the enzyme harnesses to drive other chemical reactions that will not occur otherwise. This process is widely carried out in all known forms of life. ATPases represent a complex enzyme system which requires $\mathrm{Mg}^{2+}, \mathrm{Ca}^{2+}, \mathrm{Na}^{+}$and $\mathrm{K}^{+}$ions for 
their activity. They are not only responsible for asymmetric distribution of $\mathrm{Na}^{+}$and $\mathrm{K}^{+}$ions across the cell membrane but also in junction with other transport proteins, mediate the bulk movement of ions and fluids in a variety of tissues. The enzymes $\mathrm{Na}^{+} / \mathrm{K}^{+}$ATPases and $\mathrm{Mg}^{2+}$ ATPases are relatively sensitive to certain classes of heavy metals and other pollutants. It has been observed that toxicosis from pollutants may develop primarily from ATPases inhibition.

Magnesium ATPase (Mg-ATPase) is an ATPase that pumps magnesium. It is found in erythrocytes. It is encoded by the gene ATP3. $\mathrm{Ca}^{2+}$ plays multiple roles in biological systems acting both as an intracellular second messenger, and as a key factor (extracellularly) in adhesion and movement. ${ }^{2}$

Aluminium is one of the most abundant elements found in the environment and human exposure to this metal is common and unavoidable. Although, it is considered a non-essential element for living organisms, the reported neurotoxicity of aluminium raises the medical interest. Due to its high reactivity aluminium is not found in the free state in nature. Chemical compounds of aluminium occur typically in the trivalent value state $\left[\mathrm{Al}_{3}\right]$. The uptake of aluminium can take place through food, through breathing and by skin contact. ${ }^{3}$ Long lasting uptakes of significant concentrations of aluminium can lead to serious health effects, such as damage to the central nervous system, dementia, loss of memory, severe trembling. ${ }^{4}$ Aluminium also has direct effects on haemotopoesis and iron metabolism. Excessive concentrations of aluminium may induce microcytic anaemia. Aluminium toxicity may often results in increased reticulocyte count, decreased mean corpuscular volume, and corpuscular haemoglobin. ${ }^{5,6}$

Salacia oblonga (SO) has been used for thousands of years in Ayurvedic medicine for the oral treatment of diabetes. Extracts of various Salacia species have been shown to inhibit the activity of intestinal $\alpha$-glucosidases. Salacia oblonga root has anti-diabetic and anti-obese properties. For thousands of years, it has been used in the treatment of diabetes, diarrhea, arthritis, fevers, obesity, gonorrhea, rheumatism, itching, and asthma. As far as its use in diabetes, several animal and some human studies have shown that this plant species causes lowering of blood sugar. ${ }^{7}$ A few studies in rodents suggest that this herbal supplement has minimal side effects. However, the side effects cannot be predicted in humans, untill it has been tested in humans on a large scale.

The current study was designed with an objective to determine the effect of Salacia oblanga (extract) and activity of ATPase enzyme due to aluminum induced alteration and hematological changes in Wistar albino rats.

\section{METHODS}

The extract of Salacia oblonga (ESO) was obtained from the Department of Pharmacology and Environmental
Toxicology, Dr. A.L.M. Post Graduate Institute of Basic Medical Sciences (Sekkizhar Campus), Taramani, Chennai. The extract was dark brown colour powder and stored in refrigerator at $4^{\circ} \mathrm{C}$.

\section{Chemicals used}

Aluminium chloride $\left(\mathrm{AlCl}_{3}\right)$ was purchased from Sigma Chemical Co. (St. Louis, MO, USA). All the other chemicals and reagents used were of analytical grade.

\begin{abstract}
Animals
Wistar strain male albino rats of about 120-200 gm are used for this study. All animal experiments were performed after obtaining prior approval from the Institutional Animal Ethical Committee (IAEC) governed by Committee for the Purpose of Control and Supervision of Experiments on Animals (CPCSEA) guidelines, Government of India.
\end{abstract}

\section{Acute toxicity study}

This toxicity study was designed as per the OECD guidelines for the testing of chemicals, Acute Oral Toxicity (Acute Toxic Class Method), Guidelines 423. The Wistar albino rats were divided into control and test groups with six animals each. The control group rats received the double distilled water $(1 \mathrm{ml})$, while the test group rats got graded doses of the extracts orally, were observed for mortality till $72 \mathrm{hr}$ and the dose was calculated.

\section{Animal housing}

The animals were housed in autoclavable polypropylene cages over husk beddings. The bedding material was changed twice a week under controlled environment (Temperature: $23 \pm 4$ and Humidity: $50-70 \%$ ) and a $12 \mathrm{hr}$ light and dark cycle was maintained. The albino rats were fed with a commercial pellet diet (M/s Hindustan foods Ltd., Bangalore, India) and water ad libitum.

\section{Experimental design}

The experimental animals were divided into four groups, each group comprising of six animals for 36 days of experimental duration.

\section{Group 1}

Control rats administered orally with $1.0 \mathrm{ml}$ double distilled water daily till the end of experimental period.

\section{Group 2}

Rats administered orally with aluminium chloride (300 $\mathrm{mg} / \mathrm{kg} \mathrm{b.w)} \mathrm{alone.}$ 


\section{Group 3}

Rats administered orally with Salacia oblonga extract (SOE) $(67 \mathrm{mg} / \mathrm{kg} \mathrm{b.w})$.

\section{Group 4}

Rats administered orally with both aluminum chloride $\left(\mathrm{Alcl}_{3}\right)$ and Salacia oblonga extract.

\section{Treatment schedule}

Animals were acclimatized for 15 days under the laboratory conditions and treatment was started after the period of acclimatization. The animals were assessed daily for their body weight and behaviour. The extract was weighed accurately in electronic balance, dissolved in double distilled water and made it uniform by using the hand homogenizer.

\section{Collection of tissue samples for biochemical analysis}

At the end of the experimental period on 36th day, all the animals were anaesthetized under mild ether anesthesia and blood was collected by retro orbital vein puncture. The animals were subsequently sacrificed by cervical decapitation and the tissue (cortex) was excised quickly. The tissue was washed in physiological saline to remove blood clot and other tissue materials.

\section{Collection of blood sample}

The blood samples were collected and used it for measuring haematological parameters (red blood cell counts, total white blood cell counts in whole blood, hemoglobin and different types of leukocytes) by the procedures as described by Dacie et al. ${ }^{8}$

\section{Preparation of tissue homogenate}

The tissues were homogenized using $0.1 \%$ Tris HCL buffer ( $\mathrm{pH}$ 7.4). The homogenate was centrifuged at $12,000 \mathrm{rpm}$ and $4^{\circ} \mathrm{C}$ for 30 minutes and Supernatant was used as sample for biochemical investigations.

\section{Biochemical estimations}

\section{Analysis of protein}

The protein content was estimated by the method of Lowry et al.

\section{ATPase}

The liberation of inorganic phosphorous on incubation of the tissue extract in a medium containing Tris- $\mathrm{HCl}$ buffer, $\mathrm{NaCl}, \mathrm{KCl}, \mathrm{MgCl}_{2}, \mathrm{CaCl}_{2}$ and ATP was measured spectrophotometrically.

\section{Statistical analysis}

All values were expressed as mean \pm SD. The data were statistically analyzed using one way ANOVA followed by Tukey's HSD multiple range test and differences below $\mathrm{P}<0.05$ are considered as significant.

\section{RESULTS}

\section{Acute toxicity studies}

During acute toxicity testing, by oral administration of the SOE, no mortality was seen up to $2000 \mathrm{mg} / \mathrm{kg}$ in Wistar albino rats.

\section{Effect on protein expression level}

Figure 1 presents the protein expression levels in brain cortex in study groups. The levels of protein were not diminished in control group. The level was significantly decreased in the cortex in the other two drug treated groups respectively when compared to Group $2(\mathrm{p}<0.05)$.

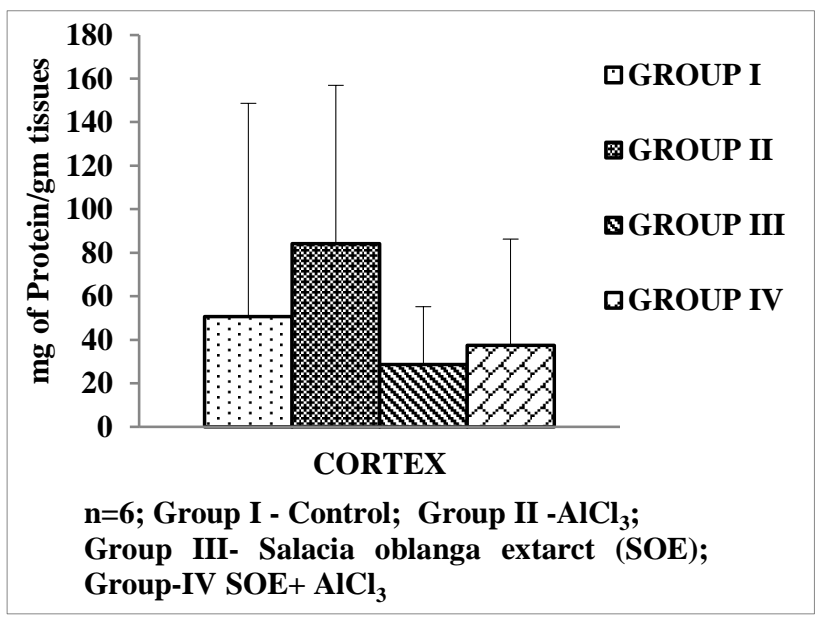

Figure 1: Estimation of protein in brain cortex of rat exposed to Alcl3, SOE and their combination for 36 days.

\section{Effects on $\mathrm{Na}^{+}$-ATPase activity}

Figure 2 shows that the oral administration of $\mathrm{Alcl}_{3}$ for 36 days significantly $(\mathrm{p}<0.05)$ decreased the activity of ATPase in brain cortex when compared to the control. In contrast, this activity was found to be significantly $(\mathrm{p}<0.05)$ increased in $\mathrm{Alcl} 3+\mathrm{SOE}$ treated group when compared to $\mathrm{Alcl}_{3}$ treated group.

\section{Effects on $\mathrm{Mg}^{2+}$-ATPase activity}

The data obtained in the present study showed that the oral administration of $\mathrm{Alcl}_{3}$ for 36 days significantly $(\mathrm{p}<0.05)$ decreased the activity of Mg-ATPase in brain cortex when compared to the control. In contrast, this activity was found to be significantly $(\mathrm{p}<0.05)$ increased in SOE alone 
and $\mathrm{Alcl}_{3}+\mathrm{SOE}$ treated groups when compared to $\mathrm{Alcl} 3$ treated group (Figure 3).

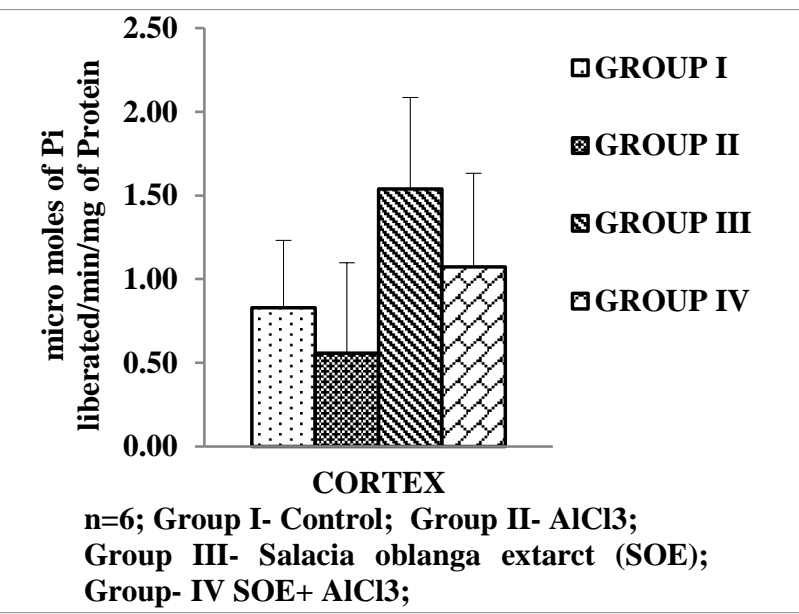

Figure 2: Estimation of Na+-K+-ATPase activity in brain cortex of rat exposed to Alcl3, SOE and their combination for 36 days.

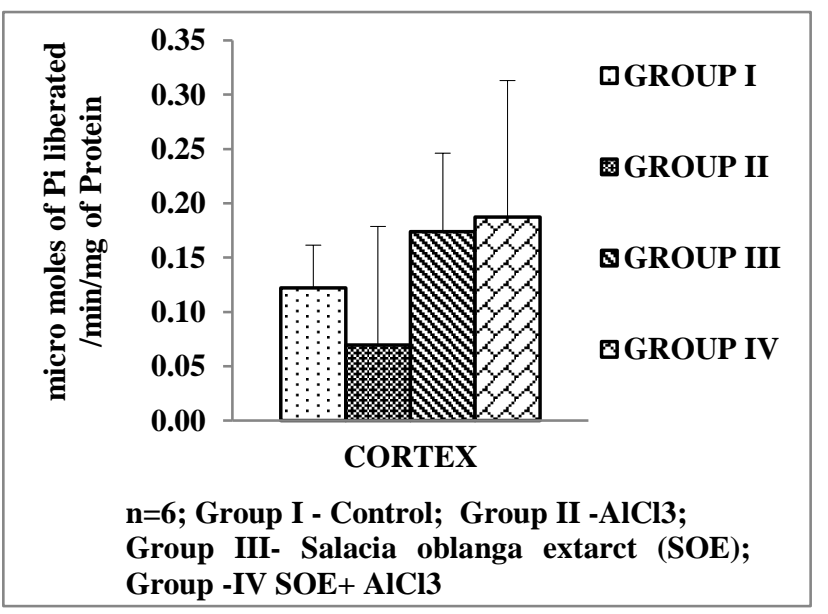

Figure 3: Estimation of Mg2+-ATPase activity in brain cortex of rat exposed to Alcl3, SOE and their combination for 36 days.

\section{Effects on $\mathrm{Ca}^{2+}$-ATPase activity}

Figure 4 demonstrates that the oral administration of $\mathrm{Alcl}_{3}$ for 36 days significantly $(\mathrm{p}<0.05)$ decreased the activity of calcium ATPase in brain cortex when compared to the control. In contrast, this activity was found to be significantly $(\mathrm{p}<0.05)$ increased and same as in Group 3 and 4 groups respectively when compared to Group 2.

\section{Effects on blood parameters}

Figure 5 explains that the oral administration of $\mathrm{Alcl}_{3}$ for 36 days significantly $(\mathrm{p}<0.05)$ decreased the activity of $\mathrm{RBC}$ when compared to the control. In contrast, this activity was found to be increased in SOE and Alcl3+SOE treated groups when compared to $\mathrm{Alcl}_{3}$ treated group. $\mathrm{Alcl}_{3}$ significantly decreased the count of neutrophils and basophils and increased the count of lymphocyte and monocytes compared to control group. This effect was reversed significantly in Group 3 and 4 when compared to Group 2 (Figure 6).

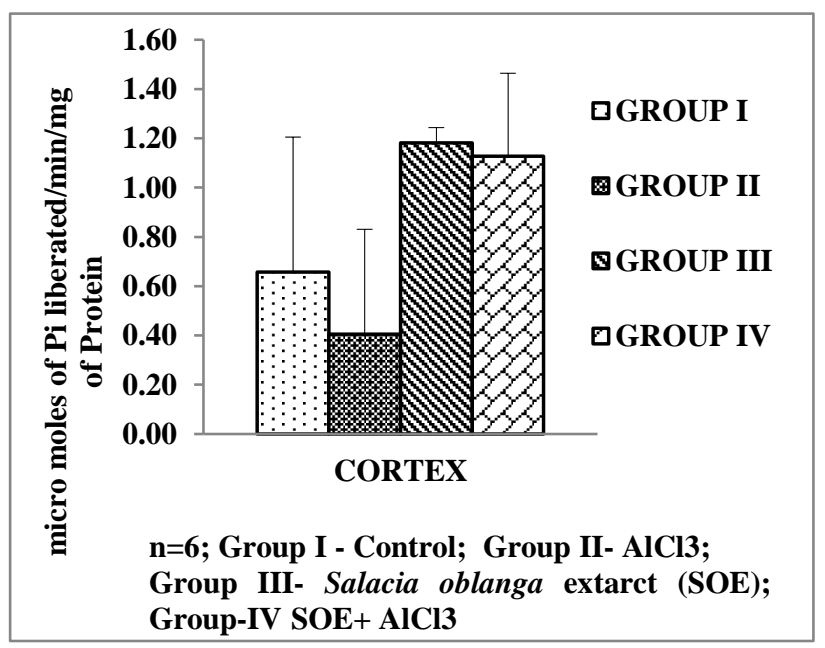

Figure 4: Estimation of CA2+ ATPase activity in brain cortex of rat exposed to Alcl3, SOE and their combination for 36 days.

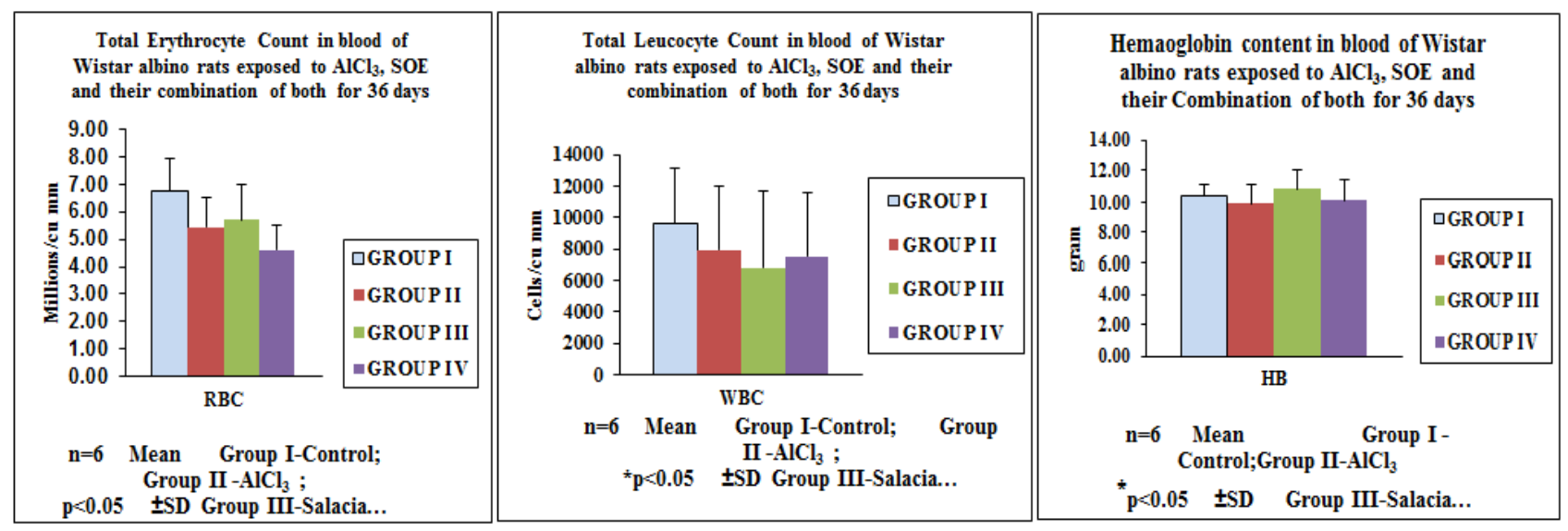

Figure 5: Estimation of blood parameters in rats when exposed to Alcl, 3 , SOE and their combination for 36 days. 


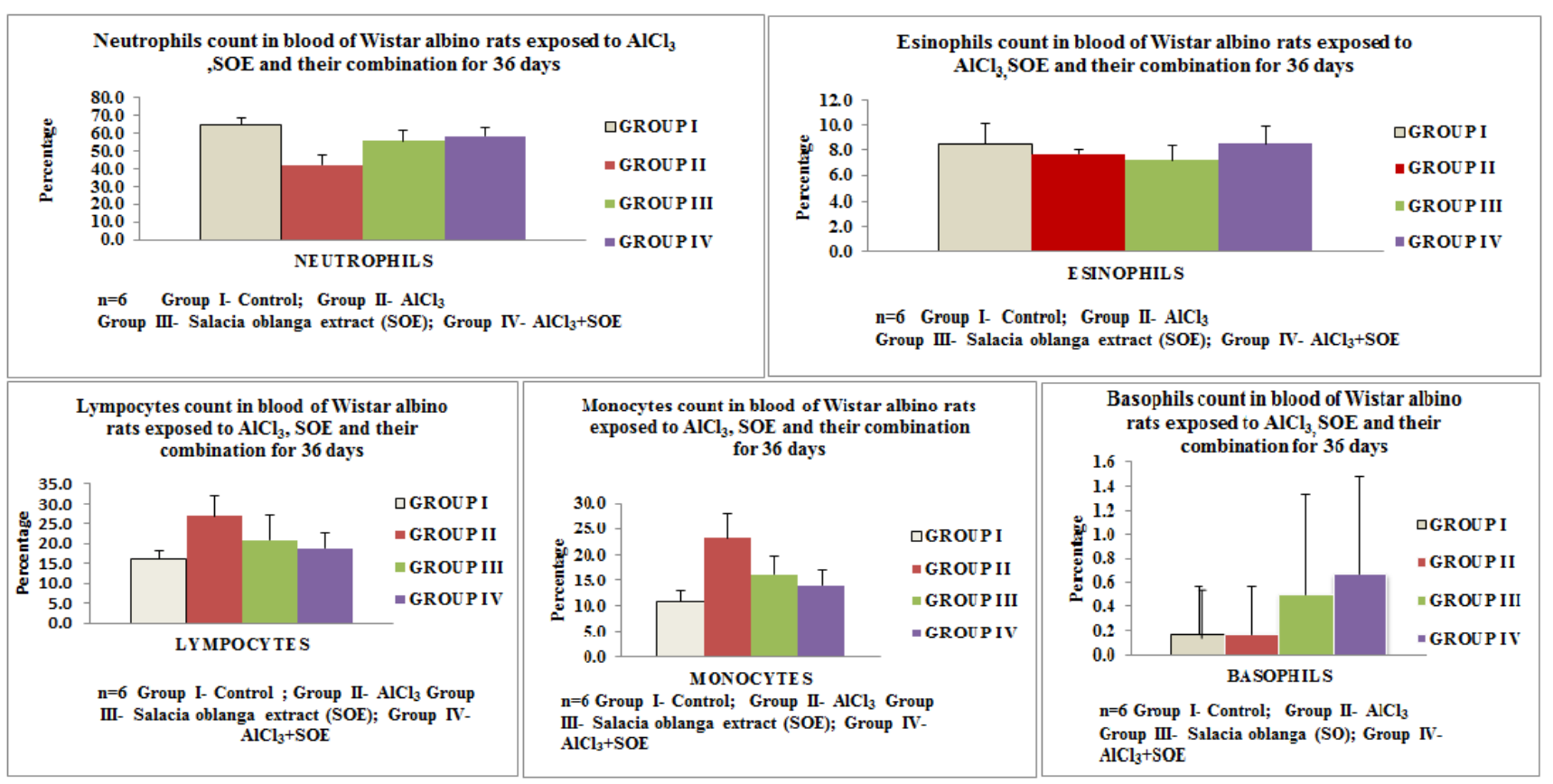

Figure 6: Estimation of differential leucocyte count in rats when exposed to $\mathrm{Alcl}_{3}$, SOE and their combination for 36 days.

\section{DISCUSSION}

Aluminium is the most abundant metal in in earth's crust and its high prevalence heavily contaminated the environment. ${ }^{9}$ Aluminium is such an element that appears to have beneficial effects on living cell. Exposure to higher concentration of aluminium leads to DNA damage of tissues and produces adverse epigenetic effects. ${ }^{10,11}$

Results of the current study demonstrates that aluminium significantly $(p<0.05)$ decreased the ATPase activities of membrane enzymes compared to control group and groups treated with drug and with aluminium together. Pretreatment with SOE alone and in combination with aluminum increased the activities of the ATPase enzymes in brain cortex. These observations are in consistent with the findings of Sumathi et al, who reported a significant decrease in $\mathrm{Na}^{+} / \mathrm{K}^{+}$ATPase, $\mathrm{Mg}^{2+}$ ATPase and $\mathrm{Ca} 2+$ ATPase in cerebral cortex of rats when compared with control group and in pre-treated groups. ${ }^{12}$

Administration of aluminium significantly altered the levels of haematology indices $(\mathrm{p}<0.05)$. A significant decrease in haemoglobin, $\mathrm{RBC}$, and in differential counts except in lymphocyte and monocyte was observed in rats treated with aluminium. Aluminium toxicity induced anaemia, leucopenia and thrombocytopenia. These observations were consistent with the findings of Samani et al who reported a decrease in haematology indices as well as related markers in humans exposed to chronic aluminium citrate exposure. ${ }^{13}$ Significant improvement in hematology indices was observed in pre-treated groups.

\section{CONCLUSION}

The results of the present investigation indicate that the hydroalcoholic extract of Salacia oblonga possesses a good activity against membrane ATPases and effective in counteracting changes in lymphocyte and monocyte count. However, its clinical usefulness should be investigated with further studies.

Funding: No funding sources

Conflict of interest: None declared

Ethical approval: The study was approved by the Institutional Ethics Committee

\section{REFERENCES}

1. Mukherjee PK, Nema NK, Venkatesh P, Debnath PK. J Ethnopharmacol. 2012:143(2)424-34.

2. Ismail TS, Gopalakrishnan S, Begum VH, Elango V. Antiinflammatoryactivity of Salacia oblonga Wall and Azimatetracantha Lam. J Ethnopharmacol. 1997;56(2):145-52.

3. ATSDR (Agency for Toxic Substances and Disease Registry). Toxicological profile for aluminum and compounds. Atlanta, GA: U.S Department of Health and Human Services, Public health service; 2005.

4. Palani S, Raja S, Nirmal Kumar S, Senthil Kumar B. Nephroprotective and antioxidant activities of Salaciaoblonga on acetaminophen-induced toxicity in rats. Natural Product Res. 2011;25(19):1876-80. 
5. Mahieu S, Contini M, Gonzalez M, Millen N, Elias MM. Aluminum toxicity- Hematological effects. Toxicol Lett. 2000;111(3):235-42.

6. Zaman K, Zaman W, Siddique H. Hematological and enzymatic results of aluminum intoxication in rats. Comparative Biochemistry and Physiol. 1993;105(1):73-6.

7. Singh NK, Biswas A, Rabbani SI, Devi K, Khanam S. Preventive Effect of Hydroalcoholic Extract of Salacia oblonga Root Bark on Mitomycin-CInduced DNA Damage Using Micronucleus Test System in Rats. Pharmacologyonline. 2009;21:127-33.

8. Dacie JV, Lewis SM. Investigation of haematological disorders. Practical hematology. $10^{\text {th }}$ ed. United Kingdom: Churchill Livingstone Elsevier. 2006:177180.

9. Anacletus FC, Onyegeme-Okerenta BM. Induction of Haematological and Lipid Profile Changes by Aluminium-Induced Toxicity and Ameliorative Effects of Selected Antioxidants on Wistar Rats. Health Sciences Res. 2016;3(3):30-4.

10. Exley C, Charles LM, Barr L, Martin C, Polwart A, Darbre PD. Aluminium in human breast tissue. J Inorganic Biochem. 2007;101(9):1344-6.
11. Lankoff A, Banasik A, Duma A. A comet assay study reveals that aluminium induces DNA damage and inhibits the repair of radiation-induced lesions in human peripheral blood lymphocytes. Toxicology Letters. 2006;161(1):27-36.

12. Sumathi T, Shobana C, Mahalakshmi V, Sureka R, Subathra M, Vishali A, et al. Oxidative Stress in Brains Of Male Rats Intoxicated With Aluminium And Neuromodulating Effect Of Celastrus Paniculatus Alcoholic Seed Extract. Asian J Pharm Clin Res. 2013;6(3):80-90.

13. Samani KG, Farrokhi E, Samani NM, Moradi HH. The effect of Aluminum on the increasing risk of developing anemia among workers of tile production plants. Int J Epidemiol Res. 2015;2(1):24-9.

Cite this article as: Divyashanthi CM, Nandhini A, Datchanamurthy B. Effects of Salacia oblonga on aluminium induced changes in membrane ATPases in brain cortex and hematological parameters in Wistar albino rats. Int $\mathbf{J}$ Basic Clin Pharmacol 2019;8:1215-20. 